\title{
Transformasi Kelembagaan Kelompok Tani-Ternak Sapi Di Desa Genggelang Kecamatan Gangga Kabupaten Lombok Utara
}

\author{
Soekardono*1, M. Ichsan $^{2}$, I.G. Lanang Media ${ }^{1}$, Moh. Prasetyo Nugroho ${ }^{1}$, Ashari $^{3}$ \\ ${ }^{1)}$ Laboratorium Sosial Ekonomi Peternakan, Fakultas Peternakan Universitas Mataram \\ ${ }^{2)}$ Laboratorium Produksi Ternak Unggas, Fakultas Peternakan Universitas Mataram \\ ${ }^{3)}$ Laboratorium Produksi Ternak Potong, Fakultas Peternakan Universitas Mataram
}

Kata Kunci: kelompok taniternak, orientasi bisnis, peternak sapi, rekayasa sosial

\begin{abstract}
Abstrak: Kelompok tani-ternak sapi di Kabupaten Lombok Utara umumnya hanya berfungsi sebagai kandang kolektif untuk menjaga keamanan dari pencurian ternak, belum berfungsi sebagai kemompok pengembangan bisnis. Tujuan akhir pengabdian kepada masyarakat ini adalah untuk mengembangkan dan memberdayakan kelompok tani-ternak sapi agar kelompok tersebut dapat menjadi kelompok yang maju dan mandiri berbasis prinsip-prinsip bisnis. Pengabdian ini dilaksanakan berdasarkan program penyuluhan peternakan sapi potong berbasis kelompok. Pengabdian ini dilakukan pada kelompok tani-ternak sapi yang belum tersentuh oleh layanan Pemerintah baik Pemerintah Kabupaten maupun Provinsi. Tujuan pertama pengabdian ini adalah memberdayakan kelompok tani-ternak sapi agar memiliki organisasi dan adminstrasi yang tertib dan lengkap. Tujuan kedua, para peternak memiliki pengetahuan dan ketrampilan dalam mengelola usaha ternak sapi berbasis bisnis dan pengurus kelompok memiliki ketrampilan manajemen yang memadai. Peserta penyuluhan dalam rangka pengabdian ini sebanyak 20 orang terdiri atas pengurus dan anggota dari satu kelompok taniternak "TIOQ TUNAQ". Penyuluhan dilaksanakan dalam dua kali pertemuan. Pertemuan pertama, memberikan motivasi kepada pengurus dan peternak agar mereka bersemangat mengelola usaha ternaknya diakhiri dengan menyusun pengurus kelompok secara demokratis. Pertemuan kedua, memberikan penyuluhan tentang sistem produksi ternak sapi dan manajemen bisnis pada usaha ternak sapi. Hasil dari pengabdian tahap awal ini adalah (1) telah terbentuk kelompok tani-ternak sapi secara definitif, yaitu "Kelompok Tani_Ternak TIOK TUNAK" lengkap dengan kepengurusan dan perlengkapannya; (2) para peternak telah termotivasi untuk mengusahakan ternak sapi dengan menggunakan prinsipprinsip ekonomi berbasis teknologi; dan (3) telah tersusun program kerja kelompok tani-ternak. Pengabdian ini diharapkan dapat berlanjut sampai tujuan akhir tercapai, yaitu terbentuk kelompok tani-ternak maju dan mandiri.
\end{abstract}

\section{Korespondensi: kardonowiyono@yahoo.com}

\section{PENDAHULUAN}

Lombok Utara merupakan salah satu kabupaten di Pulau Lombok yang memiliki keunggulan komparatif untuk pengembangan ternak sapi karena sebagian besar lahannya merupakan lahan kering. Luas lahan pertanian menurut penggunaannya di Kabupaten Lombok Utara terdiri dari sawah 8.918 ha $(27,64 \%)$, tegal/kebun 19.239 ha $(59,63 \%)$, dan ladang 4.105 ha (12,72\%) (Lombok Utara Dalam Angka, 2017). Lahan pertanian terutama tegal/kebun dan ladang sangat potensial sebagai sumber pakan ternak sapi. Disamping itu terdapat cukup luas lahan perkebunan kakao dan lahan kehutanan yang juga potensial sebagai 
sumber pakan. Perkebunan kakao dapat diintegrasikan dengan usaha ternak sapi sehingga pendapatan petani-peternak meningkat.

Kecamatan Gangga merupakan salah satu kecamatan di Kabupaten Lombok Utara (KLU) yang memiliki lahan perkebunan terluas dibanding dengan kecamatan lainnya. Komoditas lahan perkebunan paling banyak di Kecamatan Gangga adalah Kakao. Kecamatan Gangga memiliki luas perkebunan sekitar 5.000 ha, hutan Negara juga sekitar 5.000 ha, dan tegal/kebun sekitar 2.000 ha. Lahan-lahan tersebut merupakan sumber pakan ternak sapi potensial. Hasil sisa dan limbah produk perkebunan kakao sangat potensial sebagai bahan pakan ternak sapi. Namun demikian, para peternak sapi belum optimal memanfaatkan hasil sisa dan limbah produk pertanian dan perkebunan sebagai pakan ternak. Para peternak masih memilih memberikan pakan rumput alam yang diperoleh secara cut and carry. Para peternak masih beranggapan bahwa pakan terbaik bagi ternak sapinya adalah rumput. Dengan sistem penyediaan pakan demikian tentu jumlah pakan yang dapat disediakan per harinya sangat terbatas dan sangat tergantung dari musim. Kondisi demikian menyebabkan jumlah sapi yang dapat dipelihara juga terbatas, hanya 2-3 ekor per rumah tangga. Skala pemeliharaan yang kecil tentu juga akan menghasilkan pendapatan yang kecil. Oleh karena itu perlu diintroduksi teknologi pakan agar para peternak dapat meningkatkan skala usahanya.

Untuk mengoptimalkan sumber daya peternakan terutama potensi pakan ternak tersebut, diperlukan pengetahuan dan ketrampilan para peternak mengenai teknologi pakan. Penguasaan teknologi pakan saja belum cukup untuk mengoptimalkan usaha ternak sapi, perlu penguasaan teknologi lainnya seperti teknologi produksi, reproduksi, dan manajemen usaha. Kelompok tani-ternak sapi merupakan kelembagaan paling strategis untuk mengoptimalkan usaha ternak sapi. Oleh karena itu diperlukan transformasi kelembagaan secara bertahap dari kelompok tani-ternak sapi yang umumnya masih pemula menjadi kelompok tingkat utama. Melalui kelompok tani-ternak diharapkan usaha ternak rakyat akan menjadi efisien dan memberikan pendapatan yang layak.

Menurut Soekardono (2009), usaha ternak sapi rakyat memiliki peran ganda bagi para petani-peternak di pedesaan, diantaranya adalah sebagai sumber pendapatan rumah tangga, sebagai tabungan yang sewaktu-waktu dapat diuangkan, dan sebagai sumber pupuk organik. Ternak sapi yang dipelihara para peternak di Provinsi Nusa Tengggara Barat, termasuk di Kabupaten Lombok Utara, adalah ternak Sapi Bali. Sapi Bali memiliki beberapa keunggulan dibanding jenis sapi lainnya, diantaranya umur pubertas dan calving interval umumnya lebih pendek serta lebih kuat pertahanan tubuhnya terhadap lingkungan yang buruk (Fattah, 2012).

Dilihat dari kondisi lahan dan pola pertaniannya, di wilayah Desa Genggelang sangat cocok untuk penerapan sistem integrasi tanaman-ternak (SITT). Manfaat SITT menurut Devendra (1993) dalam Diwyanto (2001), yaitu (1) dalam upaya diversifikasi penggunaan sumberdaya produksi, (2) mengurangi terjadinya resiko, (3) efisiensi penggunaan tenaga kerja, (4) efisiensi penggunaan komponen produksi, (5) mengurangi ketergantungan energi kimia dan energi biologi serta masukan sumberdaya lainnya dari luar, (6) sistem ekologi lebih lestari dan tidak menimbulkan polusi sehingga melindungi lingkungan hidup, (7) meningkatkan output, dan (8) mengembangkan rumah tangga petani yang stabil. 


\section{METODE PELAKSANAAN}

Metode yang digunakan dalam kegiatan Pengabdian Kepada Masyarakat ini pada prinsipnya adalah metode penyuluhan pertanian. Penyuluhan ini bertujuan untuk meningkatkan pengetahuan, ketrampilan, dan sikap para peternak terkait dengan teknologi peternakan. Setelah para peternak menerapkan teknologi tersebut diharapkan pendapatan usahanya meningkat. Selama ini para peternak masih menganggap bahwa usaha ternak sapi hanya sebagai usaha sambilan. Oleh karena itu, umumnya jumlah sapi yang dipelihara hanya 2 - 3 ekor, sesuai dengan kemampuan tenaga kerja keluarga untuk menyediakan pakan seharihari. Para peternak belum memanfaatkan teknologi pakan, misalnya teknologi penyimpanan bahan pakan untuk jangka waktu tertentu. Para peternak masih melakukan penyediaan pakan dengan system cut and carry. Jadi, setiap hari peternak harus mencari pakan untuk kebutuhan hari itu. Kondisi demikian tentu tidak efisien dan tidak menentu.

Kegiatan-kegiatan yang dilaksanakan dalam penyuluhan peternakan ini adalah sebagai berikut:

1. Ceramah umum untuk memberi motivasi kepada para peternak dan pengurus kelompok agar mereka menyadari dan meyakini bahwa usaha ternak sapi dapat memberikan sumbangan yang besar dalam pendapatan rumah-tangga.

2. Pelatihan manajemen produksi dan penerapan panca usaha ternak sapi disertai praktek di kandang ternak dengan harapan para peternak trampil, mampu, dan mau menerapkan teknologi pakan, produksi, dan reproduksi dalam usaha ternak sapinya.

3. Pelatihan manajemen usaha ternak sapi (rencana bisnis, analisis biaya-pendapatan, dan pemasaran) dengan harapan para peternak mampu mengelola usaha berbasis bisnis dengan tujuan untuk memperoleh pendapatan maksimal.

4. Pelatihan manajemen kelompok tani-ternak yang hanya diikuti oleh pengurus kelompok dengan harapan para pengurus memiliki ketrampilan manajerial untuk mengembangkan kelompoknya menjadi kelompok bisnis yang menguntungkan..

Kegiatan penyuluhan ini disertai bantuan perlengkapan administrasi seperti buku induk perkembangan ternak, buku tamu, buku notulen rapat anggota, alat tulis, white board, dan papan nama kelompok. Pengabdian ini dilaksanakan selama 2 (dua) kali dalam satu bulan pada hari Sabtu.

\section{HASIL DAN PEMBAHASAN}

\section{Macam Kegiatan}

Kegiatan pengabdian kepada masyarakat ini dilakukan pada kelompok tani-ternak sapi “TIOQ TUNAQ” di Dusun Belatak, Desa Genggelang/Desa Persiapan Segara Katon, Kecamatan Gangga, Kabupaten Lombok Utara. Dalam pengabdian masyarakat ini, sengaja dipilih kelompok tani-ternak yang belum tersentuh oleh program pemerintah. Dalam kelompok tani-ternak ini telah tergabung 30 peternak, dengan rata-rata pemilikan ternak sapi 3 (tiga) ekor sehingga terdapat sekitar 90 ekor sapi dari berbagai jenis kelamin dan umur. Kelompok ini belum berfungsi sebagai kelompok bisnis, sementara ini hanya berfungsi sebagai kandang kolektif, lebih ditujukan untuk menjaga keamanan dari pencurian ternak.

Oleh karena itu, kegiatan pengabdian masyarakat ini pertama-tama yang dilakukan adalah membentuk kepengurusan yang definitif beserta kelengkapannya dan memberikan 
bantuan sarana-prasarana administrasi berupa papan nama kelompok, papan struktur organisasi, buku besar untuk administrasi kondisi ternak, buku tamu, dan buku catatan rapat pengurus. Kegiatan berikutnya adalah memberikan penyuluhan kepada peternak anggota mengenai manajemen produksi ternak sapi, pengelolaan kelompok tani-ternak, dan manajemen usaha dalam kelompok. Peserta yang terlibat dalam kegiatan pengabdian masyarakat ini sebanyak 20 orang peternak.

Kegiatan pengabdian dilaksanakan dalam tiga kali pertemuan, setiap kali pertemuan sekitar 3 (tiga) jam efektif. Pada pertemuan pertama, diberikan motivasi kepada para peternak agar lebih semangat berusaha ternak sapi dilanjutkan dengan pembentukan kelompok tani-ternak melalui musyawarah. Melalui musyawarah tersebut berhasil ditetapkan nama kelompok, yaitu kelompok tani-ternak "TIOK TUNAK” dengan ketua Sdr. Ardip, sekretaris Sdr. Sahrip, dan bendahara Sdr. Ardi. Pada pertemuan kedua, diberikan penyuluhan kepada pengurus dan anggota kelompok mengenai manajemen produksi dan manajemen bisnis usaha ternak sapi. Pada pertemuan ketiga, khusus pengurus diberikan pelatihan manajemen organisasi kelompok tani-ternak.

\section{Pencapaian Tujuan}

Tujuan pokok pengabdian kepada masyarakat ini adalah meningkatkan produksi dan pendapatan usaha ternak sapi melalui kelompok tani-ternak. Dalam upaya mencapai tujuan pokok tersebut, perlu diberdayakan dan dikembangkan kelompok tani-ternak yang telah ada, sehingga kelompok tani-ternak tersebut dapat menjadi kelompok tani-ternak yang berorientsi bisnis. Untuk itu, dalam pengabdian masyarakat ini dilakukan kegiatan-kegiatan seperti yang diuraikan pada sub bab macam kegiatan di atas. Pelaksanaan kegiatan pengabdian kepada masyarakat ini berlangsung dengan baik. Selama penyuluhan, para peternak sangat aktif dalam diskusi, mulai dari penyampaian masalah-masalah sampai kepada rencana penyelesaian masalah. Masalah-masalah yang dialami para peternak adalah permodalan, penyediaan pakan pada musim kemarau, pembuatan pupuk organik, dan pengembangan usaha.

Permodalan untuk kelompok ini sangat penting karena sebagian besar peternak merupakan peternak pengadas. Peternak pengadas hanya memperoleh $50 \%$ dari pendapatan bersih. Dengan perkiraan pendapatan bersih usaha ternak sapi sekitar Rp. 3 juta,- per ekor per tahun, berarti jika para peternak pengadas memelihara 2 ekor, tiap tahun mereka hanya akan memperoleh pendapatan Rp. 3 juta per tahun atau hanya sekitar Rp. 250 ribu per bulan. Pendapatan sebesar ini tentu tidak dapat untuk memenuhi kebutuhan rumah tangga seharihari. Oleh karena itu, solusi untuk meningkatkan pendapatan peternak sapi adalah dengan membantu permodalan untuk pengadaan sapi induk atau sapi bakalan dengan jumlah layak ekonomi, yaitu sekitar 5 ekor sapi. Bantuan modal tersebut harus dengan tingkat bunga murah (maksimum 6\% per tahun) dan jangka waktu pengembalian sesuai dengan masa produksi. Di samping itu modal dapat untuk pengembangan usaha non usaha ternak, misalnya perdagangan dan industri rumah tangga. 


\section{Pencapaian Sasaran}

Ditinjau dari sisi peserta, sasaran pengabdian kepada masyarakat ini adalah petanipeternak yang tergabung dalam kelompok tani-ternak dan pengurus kelompok. Jumlah petani-peternak yang berpartisipasi dalam pelatihan dalam rangka pengabdian kepada masyarakat ini sebanyak 22 orang. Jumlah anggota kelompok sebanyak sekitar 30 orang. Dengan demikian jumlah peserta pelatihan sebanyak $86 \%$ dari seluruh anggota kelompok. Dilihat dari jumlah dan keaktifan peserta selama pelatihan, sasaran pengabdian kepada masyarakat ini dapat dikatakan berhasil.

Dari sisi output, sasaran pengabdian kepada masyarakat ini adalah para peternak memiliki ketrampilan teknis dan ekonomis dalam berusaha ternak. Secara teknis, para peternak diharapkan trampil dalam melaksanakan panca usaha ternak sapi, yaitu pemilihan bibit, pemberian pakan, pemeliharaan sehari-hari, penanganan reproduksi ternak (perkawinan ternak), dan penanganan kesehatan ternak. Secara ekonomis, diharapkan para peternak memiliki kemampuan manajerial dalam berbisnis seperti mengalokasikan sumber daya secara efisien, menentukan jumlah pemeliharaan sapi yang optimal, menentukan kapan harus menjual ternak, menentukan harga jual, dan sebagainya. Dalam teknik berternak, umumnya para peternak sudah cukup trampil. Pakan ternak yang diberikan sehari-hari berupa hijauan segar berupa rumput lapangan dan jerami tanaman (kacang tanah, padi, dan jagung). Pakan tersebut disediakan secara cut and carry. Ketika musim hujan pakan tidak menjadi masalah, tetapi pada musim kemarau menjadi masalah karena umumnya lahan sumber pakan menjadi kering sehingga rumput lapangan juga menjadi kering dan tanaman pangan juga tidak ditanam.

Oleh karena itu solusi untuk mengatasi permasalahan terkait usaha ternak sapi, khususnya mengenai pakan, adalah dengan meningkatkan kemampuan manajerial peternak dan pengurus kelompok tani-ternak. Melalui pengabdian masyarakat kali ini para peternak telah menyadari dan telah tumbuh minatnya untuk berusaha ternak lebih baik. Kegiatan pengabdian masyarakat ini harus dilanjutkan dengan pemberdayaan dan pembinaan kelompok tani-ternak sampai tujuan membangun kelompok tani-ternak yang maju dan mandiri tercapai.

\section{Pencapaian Manfaat}

Manfaat penyuluhan dalam rangka pengabdian kepada masyarakat bagi para peternak adalah menambah pengetahuan dan ketrampilan berternak dan menambah ketrampilan manajerial dalam berusaha ternak sapi. Setelah mengikuti penyuluhan para peternak mulai menyadari pentingnya teknologi baik teknologi teknis, social, maupun ekonomi untuk pengembangan usaha ternak sapinya. Selanjutnya mereka nampak telah mulai berminat untuk mengembangkan usaha ternak sapinya kearah usaha yang lebih menguntungkan melalui usaha yang berbasis bisnis. Para peternak mulai menyadari bahwa dengan penerapan teknologi, khususnya teknologi pakan, akan dapat meningkatkan produksi, produktivitas, dan jumlah pemeliharaan ternak. Selama ini para peternak memelihara ternak hanya sebanyak 2-3 ekor sesuai dengan kemampuan tenaga keluarga untuk menyediakan pakan secara cut and 
carry. Para peternak belum memanfaatkan jerami tanaman pertanian secara optimal. Jerami padi, jagung, kacang tanah, dan sebagainya baru sekitar $40 \%$ dimanfaatkan oleh petanipeternak. Dengan pemeliharaan 2-3 ekor, para peternak masih dapat menyediakan pakan berupa hijauan segar. Selama ini para peternak berpikir (mindset) bahwa jerami kering kurang baik untuk pakan ternak dan merasa kasihan kepada ternaknya jika diberi pakan jerami kering.

Manfaat bagi Fakultas Peternakan Universitas Mataram, program pengabdian kepada masyarakat ini dapat menjadi jembatan penghubung antara Fakultas sebagai sumber teknologi dengan para peternak sebagai pelaku utama usaha ternak yang membutuhkan teknologi. Melalui pengabdian kepada masyarakat, Fakultas dapat mendesiminasikan hasilhasil penelitian para dosen dan mahasiswa kepada para peternak sekaligus dapat memperoleh umpan balik mengenai masalah-masalah yang dialami para peternak. Disamping itu, lokasi pengabdian kepada masyarakat dapat dikembangkan menjadi tempat praktek atau PKL mahasiswa.

Manfaat bagi Pemerintah, kelompok tani-ternak yang telah menerapkan teknologi peternakan dan telah menerapkan manajemen usaha berorientasi bisnis, dapat dijadikan percontohan dalam rangka pengembangan usaha ternak sapi yang lebih produktif dan menguntungkan. Usaha ternak sapi yang produktif selain akan memberikan pendapatan yang layak bagi peternak, juga akan mendukung tercapainya program NTB-BSS dan sekaligus mendukung program swasembada daging sapi nasional (PSDS).

\section{Faktor Penghambat dan Pendukung}

Beberapa faktor penghambat dalam pengembangan usaha ternak sapi, khususnya pada kelompok tani-ternak "TIOQ TUNAQ" adalah:

1) Para peternak terbiasa memberikan pakan sapi secara cut and carry. Mencari pakan secara cut and carry tentu hanya dapat menyediakan jumlah pakan yang terbatas, tergantung pada kondisi ketersediaan pakan di lapangan dan tenaga kerja yang tersedia. Pada musim hujan, pakan hijauan cukup melimpah sehingga setiap rumah tangga taniternak tidak mengalami kesulitan mencari pakan. Namun demikian, pada musim kemarau ketersediaan pakan hijauan di lapangan sangat terbatas sehingga memerlukan tenaga dan waktu yang lebih banyak untuk mencari pakan. Kondisi demikian menyebabkan jumlah sapi yang dapat dipelihara oleh rumah tangga tani-ternak menjadi terbatas, rata-rata hanya 3 ekor. Bahkan beberapa peternak terpaksa harus menjual ternaknya pada musim kemarau karena kesulitan menyediakan pakan.

2) Para petani-peternak berpandangan bahwa usaha ternak sapi hanya sebagai usaha sambilan dan tabungan sedangkan usaha pokoknya adalah usahatani tanaman. Pandangan demikian mengakibatkan para petani-peternak kurang memiliki motivasi mengusahakan ternak sapi menggunakan prinsip-prinsip bisnis. Mereka merasa sudah cukup memelihara sapi secara tradisional.

3) Kelompok tani-ternak belum berfungsi optimal sebagai kelompok yang berorientasi bisnis. Kelompok masih berfungsi sebagai kandang kolektif, yang lebih mengutamakan fungsi pengamanan dari pencurian ternak dari pada untuk mengembangkan usaha ternak 
sapi yang lebih menguntungkan. Kelompok belum melakukan manajemen efisiensi usaha, misalnya dengan penyediaan bibit ternak yang berkualitas, melakukan penyimpanan pakan secara bersama-sama, pembuatan pupuk organik, pemasaran ternak dan hasil-hasil ikutannya secara bersama, pengembangan skala usaha, dan sebagainya. Selama ini para peternak melakukan kegiatan usaha ternak sapi secara individual (sendiri-sendiri).

4) Pengurus kelompok kurang aktif dalam mengelola kegiatan kelompok. Kelompok ini belum mendapat perhatian dari dinas yang menangani bidang peternakan, dalam hal ini Dinas Ketahanan Pangan dan Pertanian Kabupaten Lombok Utara. Selama ini belum pernah mendapat pembinaan dan bantuan dari pemerintah. Kelompok kurang aktif melakukan komunikasi dengan petugas Dinas tersebut.

5) Lokasi kandang kelompok "TIOQ TUNAQ" kurang startegis. Akses masuk ke kandang harus melalui gang-gang antar rumah penduduk. Akses dimaksud dapat diperlancar dengan memasang plang papan nama kelompok dan penunjuk arah.

Beberapa faktor pendorong dan peluang untuk pengembangan kelompok tani-ternak TIOQ TUNAQ adalah:

1). Lahan di wilayah Desa Genggelang tergolong subur dan sebagian wilayahnya merupakan lahan pertanian tanaman pangan dan sebagian lainnya perkebunan Kakao. Lahan-lahan ini memiliki potensi penyediaan pakan sapi yang cukup tinggi.

2). Para peternak di wilayah ini telah berpengalaman memelihara sapi secara turun temurun dan memiliki keinginan dan kemauan yang kuat untuk mengembangkan usaha ternak sapi dalam rangka menambah pendapatan rumah tangganya.

3). Permintaan ternak sapi baik sebagai sapi potong maupun sapi bibit sangat besar, sehingga tidak ada permasalahan dalam pemasaran ternak.

4). Institusi pendukung cukup tersedia untuk melayani para peternak dalam pengembangan usaha ternak sapi, seperti POS-IB, Puskeswan, Lembaga Penyuluhan, dan Lembaga Pemasaran.

\section{KESIMPULAN DAN SARAN}

\section{Kesimpulan}

Kesimpulan hasil pengabdian kepada masyarakat ini adalah:

1. Kelompok tani-ternak "Tioq Tunaq" masih tergolong kelompok pemula, pembinaan dari pemerintah sangat minim, pemeliharaan ternak masih tradisional dan individual, dan fungsi kelompok hanya sebagai kandang kolektif yang lebih ditujukan untuk pengamanan dari pencurian ternak.

2. Skala usaha peternak tergolong kecil dengan rata-rata pemeliharaan sapi hanya 2 ekor per peternak sehingga pendapatan usaha ternaknya rendah, hanya sekitar Rp. 3 juta per tahun.

3. Setelah mengikuti penyuluhan dalam kegiatan pengabdian kepada masyarakat, para peternak mempunyai keinginan kuat untuk mengembangkan usaha ternak sapinya.

4. Para peternak sudah memahami bahwa dengan menerapkan teknologi akan dapat meningkatkan produktivitas ternaknya dan selanjutnya akan meningkatkan pendapatannya. 
5. Pengurus kelompok tani-ternak telah menyatakan kesediaan untuk mengelola kelompok lebih baik untuk meningkatkan kelas kelompok menjadi kelas madya atau bahkan utama.

6. Oleh karena pengabdian masyarakat ini baru pada tahap menggugah kesadaran dan minat para peternak maka kegiatan penyuluhan dan pelatihan harus dilanjutkan sampai para peternak bersedia menerapkan teknologi baik teknologi yang terkait teknis maupun ekonomis.

\section{Saran}

Agar kelompok tani-ternak “Tioq Tunaq" dapat mencapai kelas kelompok madya atau utama maka disarankan hal-hal berikut:

1. Dinas Ketahanan Pangan dan Pertanian Kabupaten Lombok Utara dan Dinas Peternakan dan Kesehatan Hewan Provinsi NTB diharapkan melakukan pembinaan dan pengembangan Kelompok Tani-Ternak tersebut disertai memberikan bantuan modal untuk pembelian sapi bibit betina dan memfasilitasi sarana-prasarana untuk pengadaan stok pakan.

2. Fakultas Peternakan Unram perlu melanjutkan program pengabdian kepada masyarakat ini sehingga terjadi keberlanjutan transfer teknologi tepat guna yang diperlukan oleh para peternak.

3. Perlu adanya kerja sama antara Fakultas Peternakan Unram dengan Dinas Ketahanan Pangan dan Pertanian Kabupaten Lombok Utara untuk pengembangan usaha ternak sapi berbasis kelompok menuju kelompok yang berorientasi bisnis.

\section{DAFTAR PUSTAKA}

BPS Lombok Utara. 2012. Lombok Utara Dalam Angka 2012. Badan Pusat Statistik Kabupaten Lombok Utara: Tanjung.

BPS Lombok Utara 2017. Lombok Utara Dalam Angka 2017. Badan Pusat Statistik Kabupaten Lombok Utara: Tanjung.

Dinas Pertanian, Perkebunan, Kehutanan, Kelautan dan Perikanan Kabupaten Lombok Utara. 2016. Laporan Tahunan 2016.

Dinas Ketahanan Pangan dan Pertanian Kabupaten Lombok Utara. 2018. Data Base Peternakan 2017.

Diwyanto,K. 2001. Model Perencanaan Terpadu: Integrasi Tanaman-ternak (Crop-Livestock

System). Makalah Seminar Nasional Teknologi Peternakan dan Veteriner, Auditorium Balai Penelitian Veteriner Bogor, 17-18 September 2001.

Fattah, S. 2012. Produktivitas Ternak Sapi Bali. The Phinisi Press. Yogyakarta.

Soekardono. 2009. Ekonomi Agribisnis Peternakan: Teori dan Alikasinya. Penerbit Alademika Presssindo, Jakarta.

Soekardono dan A. Fachry. 2017. Corn And Cattle Integration to Sport NTB's One Million Cattle Programe In Lombok Island. Proceedings The 7th International Seminar On Tropiccal Animal Production, September 12-14, 2017, Yogyakarta, Indonesia. ISBN: 978-979-1115-29-9 